University for Business and Technology in Kosovo

UBT Knowledge Center

Nov 7th, 9:00 AM - 5:00 PM

\title{
Gaining Competitive Advantage in Tourism Marketing: A Text Mining Approach to Hotel Visitors' Comments in Durrës
}

Taşkın Dirsehan

Marmara University, taskin.dirsehan@marmara.edu.tr

Follow this and additional works at: https://knowledgecenter.ubt-uni.net/conference

Part of the Business Commons

\section{Recommended Citation}

Dirsehan, Taşkın, "Gaining Competitive Advantage in Tourism Marketing: A Text Mining Approach to Hotel Visitors' Comments in Durrës" (2015). UBT International Conference. 20.

https://knowledgecenter.ubt-uni.net/conference/2015/all-events/20

This Event is brought to you for free and open access by the Publication and Journals at UBT Knowledge Center. It has been accepted for inclusion in UBT International Conference by an authorized administrator of UBT Knowledge Center. For more information, please contact knowledge.center@ubt-uni.net. 
11. Shoqata e Artizaneve (Artisans Association). (2015). Retrieved June 1, 2015, from artizanati.com, http://artizanati.com/

12. Tourism, Ministry of. (2014). Draft - National Tourism Strategy 2014 - 2020. Tirane: MZHUT.

13. UNDP, CIS, UNOPS. (2011, June). Strategic Plan for Sustainable Tourism in Shkodra Region. Retrieved June 23, 2015, from Slideshare, http://www.slideshare.net

14. UNESCO, I. (1997). International Symposium "Crafts and the International market: Trade and Custom Codification". Manila, The Philippines, unesdoc.unesco.org

\title{
Gaining Competitive Advantage in Tourism Marketing: A Text Mining Approach to Hotel Visitors' Comments in Durrës
}

\author{
Taşkın Dirsehan \\ Marmara University, Department of Business Administration (Lectured in English), \\ Istanbul, Turkey \\ taskin.dirsehan@marmara.edu.tr
}

\begin{abstract}
In recent years, data are exploded and they become more unstructured as a result of increasing web pages, e-mails, social media, photos and video contents. Traditional databases are not enough now to manage such data. However, organizations should manage them to gain competitive advantages; otherwise they will go out of play. As unstructured data are increased now, companies face with 'big data' and data mining tools should be applied to transform mass data into information and even into knowledge. There are different data mining techniques providing 'business intelligence'. One of them is text mining, a powerful tool to analyze texts as main unstructured data. They are mostly available in the tourism sector in the form of tourists' satisfaction and dissatisfaction stories. In this study, text mining technique will be applied to travelers' comments about hotels located in Durrës on booking.com. This web site collects travelers' positive and negative comments separately, so it enables to analyze comments in a bipolar way. In this case, the comments represent unstructured mass data and the competitive advantage will be the knowledge of attributes of satisfaction and those of dissatisfaction. Based on the research findings, these attributes will be discussed in details. Some of them are considered as 'standards', where their existence does not create satisfaction but their lack causes dissatisfaction. On the other hand, some of them are considered as 'providing competitive advantage', where their existence creates satisfaction.

Based on Herzberg's motivational theory, it's possible to state that hotel managers should eliminate dissatisfies to achieve a standard level. In addition they have to identify and then provide satisfiers to create competitive advantage which will result in travelers' satisfaction.
\end{abstract}

Keywords: Text Mining, Data Mining, Tourism Marketing, booking.com

\section{Introduction}

The last decade has provided more data than ever before. With the introduction of social media into daily lives, increasing amounts of technology enabling the monitoring of customers' and products' movements and electronic trade systems have provided unstructured and semi-structured data. These data are not suitable for traditional relational databases, which represent data in the form of columns and rows. These datasets are called "big data" (Laudon and Laudon, 2014). The big-data movement seeks to reveal intelligence from data and transform it into a business advantage (McAfee and 
International Conference on Management, Business and Economics, Nov 2015

Brynjolfsson, 2012). In the tourism sector, where there is a huge number of customer reviews in the form of eWOM, text mining can be applied to uncover hidden patterns existing in these large datasets. In today's information era, these hidden patterns may represent competitive advantages for a company (Dirsehan, 2015). The website booking.com can be used as a big-data source since it includes travelers' reviews by dividing them into satisfaction and dissatisfaction stories. So, it makes it possible to analyze the reviews in parallel with Herzberg's two-factor motivation theory. 


\section{Summary of Literature Review}

Big data is characterized by unprecedented volume, velocity, and variety. The volume of big data is enormous. By 2012, about 2.5 exabytes of data were created each day, and they are continuing to grow every second via the Internet, customer transactions, etc. The velocity of data is even more important than the volume for many applications, since it gives companies the ability to be much more agile than their competitors. The variety of data is related to its nature. It may take the form of messages, updates, images posted on social media, readings from sensors, GPS signalsfrom cell phones, etc. (McAfee and Brynjolfsson, 2012). According to Erevelles et al. (2015), the characteristics of data (volume, velocity, and variety) available from individual datum can be considered the cause of the big data revolution, which potentially introduces new ways of understanding consumer behavior and formulating marketing strategies. These strategies also consider big data as new capital, implying that firms should allocate necessary physical, human, and organizational capital resources to benefit from big data.

Tourism marketing research has started to show an interest in big data (Dolnicar and Ring, 2014).Using GPS tracking dataand tourism behavior survey data over a period of five years, respectively, Orellana et al. (2012) and Law et al. (2011) showed ways to handle large data sets (Dolnicar and Ring, 2014). Big data represent datasets with huge volumes that are beyond the ability of traditional database-management systems to capture, store, and analyze. Instead, data mining is a tool to reveal hidden patterns and relationships in large databases. Possible extraction of information from data mining includes associations, sequences, classifications, and forecasts (Laudon and Laudon, 2014). On the other hand, social media, e-mails, reviews, etc. provide textual data. In this case, as an innovative methodology, a combination of text-mining approach and statistical analyses can be used (Gassiot and Coromina, 2013). Text-mining tools are used to analyze unstructured data (mostly in the form of text files), which are believed to represent over $80 \%$ of useful organizational information (Laudon and Laudon, 2014). Text mining can be applied to online travelers' reviews since they represent rich textual data. Xiang et al. (2015) applied text-mining approach to online reviews from Expedia.com to reveal travelers' preferences in US hotels. In this study, booking.com is used as a textual data source since it includes positive and negative comments separately. This kind of separation is useful to reveal the key components that make travelers satisfied and/or dissatisfied. The outcomes can be discussed in line with Herzberg's two-factor theory of motivation. This theory identifies two categories of motivational forces (Herzberg et al., 1962; Herzberg, 1975):

i. Motivator/Satisfiers (when motivators are present, employees feel satisfied),

ii. Hygiene/Dissatisfiers (when hygiene factors are lacking, employees experience dissatisfaction, but lack of dissatisfaction does not necessarily lead to satisfaction).

Tourism is an important sector, and it gives opportunity of development to many developing countries. Especially for Mediterranean countries, tourism is an important industry (Kushi and Caca, 2012). Thus, in this study, Durrës (in Albania) was chosen as a destination to conduct travelers' reviews about hotels. The Tirana-Durrës region is characterized by a favorable geographic area with great natural beauty, including sandy Mediterranean beaches, rocky mountains, big and small lakes, rich cultural heritage, and closeness to the European market (Scalera and Dudi, 2011).

\section{Methodology and Research Findings}

The purpose of this study is to reveal the most commonly occurring words in the satisfaction and dissatisfaction reviews. For this purpose, 500 travelers' comments were collected from booking.com, and a data warehouse was constructed. Three points were considered while choosing the reviews: i. Travelers who wrote both positive and negative comments were included in order to reveal critical words occurring in both types of comments (so, 500 positive and 500 negative comments were collected).

ii. A maximum of 30 comments for the same hotel was considered in the dataset in order to prevent bias.

iii. Comments from the most and least reviewed hotels were included in order to increase the variance (the range of hotels' total review scores was between 2.50 and 10; the median was 8.25). 
In addition, the reviews written in languages other than English were translated into English by online translator tools. In these cases, grammatical perfection was not necessary. The purpose is to simply gather the words.

The data in the warehouse were analyzed by text mining to reveal key components in the satisfaction and dissatisfaction stories. The results, together with suggested classifications, are presented in Tables 1 and 2.

The Table 1 lists the words most commonly occurring in the satisfaction reviews. Words such as "hotel" and "room" can be considered general subjects at which the reviews were directed. Some examples are as follows:

"Large and beautiful rooms, modern hotel"

"The floor of the room was very dirty."

"Excellent position of the hotel on the beach"

The words ending with a "-"indicate word-related words. For instance, "beautiful-" means "words related to beautiful" such as "beautifully."These words were suggested to be classified as descriptive adjectives. As expected, these words mostly occurred in the positive reviews.

The rest of the words are classified as Durrës-related attributessuch as location, beach, view, etc.; staff-related attributes such as staff, friendly, help, etc.; food-related attributes such as restaurant, food, etc.; and other differentiators such as clean, comfort, bed, etc.

Moreover, the words in the satisfaction reviews may be considered controllable and uncontrollable by the hotel managers. For instance, hotel managers may train the staff to make them friendly or helpful. They can manage the food offered in the restaurant. They can determine the price, improve the service, etc. On the other hand, some characteristics, such as location, place, and beach, can only be determined when the hotel is built. Thus, it is difficult to control for these factors.

Table 1. List of the Critical Words Most Commonly Occurring in the Satisfaction Stories

\begin{tabular}{|c|c|c|c|c|}
\hline & Classification & Word & $\begin{array}{c}\text { Times Occurred in } \\
\text { the Satisfaction } \\
\text { Reviews }\end{array}$ & $\begin{array}{c}\text { Times Occurred in } \\
\text { the Dissatisfaction } \\
\text { Reviews }\end{array}$ \\
\hline \multirow{2}{*}{\multicolumn{2}{|c|}{ Subject of the reviews }} & hotel & 176 & 164 \\
\hline & & room & 173 & 164 \\
\hline \multicolumn{2}{|c|}{ Descriptive Adjective } & beautiful- & 27 & 1 \\
\hline \multirow{6}{*}{$\begin{array}{c}\text { Uncontrollable } \\
\text { Factor }\end{array}$} & \multirow{6}{*}{$\begin{array}{c}\text { Durrës-Related } \\
\text { Attributes }\end{array}$} & location- & 130 & 28 \\
\hline & & beach & 182 & 71 \\
\hline & & view & 79 & 16 \\
\hline & & sea & 78 & 27 \\
\hline & & pool & 58 & 14 \\
\hline & & place & 31 & 13 \\
\hline \multirow{10}{*}{$\begin{array}{c}\text { Controllable } \\
\text { Factors }\end{array}$} & \multirow{3}{*}{$\begin{array}{l}\text { Staff-Related } \\
\text { Attributes }\end{array}$} & staff & 209 & 35 \\
\hline & & friendly- & 112 & 4 \\
\hline & & help- & 98 & 9 \\
\hline & \multirow{2}{*}{$\begin{array}{c}\text { Food-Related } \\
\text { Attributes }\end{array}$} & restaurant- & 93 & 29 \\
\hline & & food & 52 & 21 \\
\hline & \multirow{5}{*}{$\begin{array}{c}\text { Other } \\
\text { Differentiators }\end{array}$} & clean & 118 & 35 \\
\hline & & comfort- & 37 & 2 \\
\hline & & bed & 33 & 32 \\
\hline & & service- & 52 & 16 \\
\hline & & price & 45 & 20 \\
\hline
\end{tabular}

Source: Based on the author's own computations

Table 2 lists the words most commonly occurring in the negative reviews. As they are sparse in number, a classification was not suggested for these critical words. However, it is possible to say that some adjectives, such as "poor" and "dirty," can be considered "descriptive adjectives." 
Table 2. List of the Critical Words Most Commonly Occurring in the Dissatisfaction Stories

\begin{tabular}{c|c|c}
\hline Word & $\begin{array}{c}\text { Times Occurred in the } \\
\text { Satisfaction Reviews }\end{array}$ & $\begin{array}{c}\text { Times Occurred in the } \\
\text { Dissatisfaction Reviews }\end{array}$ \\
\hline breakfast & 27 & 62 \\
\hline poor & 5 & 50 \\
\hline bathroom & 10 & 42 \\
\hline shower & 4 & 40 \\
\hline book- & 4 & 33 \\
\hline dirt- & 0 & 28 \\
\hline Wi-Fi & 9 & 34 \\
\hline
\end{tabular}

Source: Based on the author's own computations

\section{Conclusion and Discussion}

The result obtained from the positive and negative reviews can be categorized in line with Herzberg's theory of motivation. Accordingly, the words existing in the negative reviews may represent hygiene factors that caused customer dissatisfaction. However, eliminating dissatisfaction does not necessitate customer satisfaction. For instance, the lack or the dysfunction of Wi-Fi is mentioned 34 times in the dissatisfaction reviews. On the other hand, its presence without problems is only mentioned 9 times in the satisfaction reviews.

In order tosatisfy customers, managers should implement motivators, which are the words that occurred in the satisfaction reviews in this case. For instance, "staff" is found 209 times in the travelers' satisfaction reviews. Some examples are as follows:

"Good staff"

"Excellent and helpful staff"

"The staff is very attentive."

"The staff was very polite."

"Wonderful friendly staff"

So, hotel managers should give due importance to staff training by measuring staff performance and determining its weaknesses. The words revealed by text mining represent a competitive advantage for tourism managers. As an aggregated result, it is possible to state that the hotels in Durrës should perform better in the areas of breakfast, bathroom, shower, booking, and Wi-Fi to eliminate travelers' dissatisfaction. However, they improved customer experience based on place, location, sea, pool, beach, view, friendly and helpful staff, food, restaurants, services, price, and comfort in developing travelers' satisfaction.

The main limitation of this study is the sample size considered for the analysis. Another one is that a single word may be repeated continuously in a single review. So, this should be controlled after the analysis. Further research may consider other sectors or other destinations in the tourism sector, which can be included to make comparisons. In conclusion, big data provide many potential research areas for academicians.

\section{References}

1. Dirsehan, T. (2015). An Application of Text Mining to Capture and Analyze eWOM: A Pilot Study on Tourism Sector. S. Rathore, \& A. Panwar in: Capturing, Analyzing, and Managing Word-ofMouth in the Digital Marketplace (s. 168-186). USA: IGI Global.

2. Dolnicar, S., \& Ring, A. (2014). Tourism Marketing Research: Past, Present and Future. Annals of Tourism Research , 47, 31-47.

3. Erevelles, S., Fukawa, N., \& Swayne, L. (2015). Big Data Consumer Analytics and The Transformation of Marketing. Journal of Business Research, In Press.

4. Gassiot, A., \& Coromina, L. (2013). Destination Image of Girona: An Online Text-Mining Approach. International Journal of Management Cases, 301-314. 
5. Herzberg, F. (1975). Work and the nature of man. New York: T.Y. Crowell.

6. Herzberg, F., Mausner, B., \& Snyderman, B. (1962). The motivation to work. New York: John Wiley and Sons, Inc.

7. Kushi, E., \& Caca, E. (2012). Informal Sector in the Sun-and-Beach Segment in Albania . EuroEconomica, 31 (1), 33-39.

8. Laudon, K., \& Laudon, J. (2014). Management Information Systems: Managing the Digital Form (13th Global Edition b.). USA: Pearson Education Limited.

9. Law, R., Rong, J., Vu, H., Li, G., \& Lee, H. (2011). Identifying Changes and Trends in Hong Kong Outbound Tourism. Tourism Management, 32 (5), 1106-1114.

10. McAfee, A., \& Brynjolfsson, E. (2012). Big Data: The Management Revolution. Harvard Business Review, October, 61-68.

11. Orellana, D., Bregt, A., Ligtenberg, A., \& Wachowicz, M. (2012). Exploring Visitor Movement Patterns in Natural Recreational Areas. Tourism Management, 33, 672-682.

12. Scalera, F., \& Dudi, V. (2011). The Local Development - The Case of Tirana-Durres Region . International Journal of Business Management and Economic Research , 2 (6), 352-358.

Xiang, Z., Schwartz, Z., Gerdes, J., \& Uysal, M. (2015). What can big data and text analytics tell us about hotel guest experience and satisfaction? International Journal of Hospitality Management , 44, 120-130. 